Volume 59, Issue 1, January-March 2021

Received 1 March 2021; Revised 10 April 2021; Accepted 22 April 2021

DOI: 10.33119/EEIM.2021.59.1

Semenets-Orlova, I., Kuzmenko, H. (2021). Development of Human Potential in the Information Society: Educational Changes and Organisational Development. Education of Economists and Managers, 59(1), 109-121.

Retrieved from: https://econjournals.sgh.waw.pl/EEiM/article/view/2454

\title{
Development of Human Potential in the Information Society: Educational Changes and Organisational Development
}

\author{
INNA SEMENETS-ORLOVA \\ Department of Public Administration, \\ Interregional Academy of Personnel Management, Kiev \\ HANNA KUZMENKO \\ Department of Public Administration, \\ Interregional Academy of Personnel Management, Kiev
}

\begin{abstract}
The information society necessitates the continuous development of education. At the same time, the development of education creates new opportunities for the development of human potential. The purpose of this work is to analyse the instrumental possibilities of educational change for the development of education in the conditions of demanding educational requests and tasks of professional work with a substantial amount of information. The approaches of joint creative activity of participants of the educational
\end{abstract}


process as effective means that create an unfavorable context for educational changes are determined. It is emphasised that the development of human potential depends on the ability of education to be flexible relative to the needs of the information society. It is determined that the transformation of the social institution of education requires radical changes in the training of a new generation of managers with a high level of professionalism, culture, innovative creative thinking. It is found out that a set of theories of organisational development is submitted methodologically capacious for creating conceptual models of management of educational changes. Reasonably scientific bases of educational changes as objects of public management are characterised by tendentiousness of public management of educational changes of collective nature.

Keywords: organisational development, educational change, education reform, human potential, development of human potential

JEL Classification Codes: D23, I21.

\section{Introduction}

The basic concept of development of education is educational change. Introduction of changes is a modern approach to management. Formation of an open polysubject educational space in which the set of new educational practices is formed expressing ideas of society of quality education is proved by application of the humanitarian approach in public management of educational changes.

Efficiency of the educational system of any country should be considered at three levels: 1 ) at the level of the person who studies (introduction of the individualised approach to motivated training); 2) at the level of the studying organisation (ensuring organisational development through continuous training of employees and management of knowledge of the organisation); 3) at the level of society which learns (support of the development of the educational environment in the society of knowledge, favourable to continuous training of individuals and the organisation) (Jacobsen \& Andersen, 2013).

The purpose of this article is to analyse the importance of educational change for the effectiveness of organisational development and the role of organisational development in the processes of human development today, in the context of the information society.

A characteristic feature of the information society is the constant growth of information, the emergence of new professions and the personal need to develop new professional competencies. This naturally causes an increase in the diversity of educational needs. New demands on education necessitate an increasingly systematic implementation of educational change. Due to the broad approach to educational 
change, the continuous development of education creates new opportunities for human potential development.

The definition of educational change is a difficult phenomenon in education, reflecting transformational dynamics of multidirectional transformations in education to a complete system, in its functions and structure, institutions, the statuses and roles of participants of the relations in education, other spheres, the organisations where educational activity is carried out (Semenets-Orlova, 2017). Educational changes are a type of social changes of the meso-level which at the level of concrete institutions and organisations can be defined as organisational changes and connected with organisational training. The problem of management of educational change is very specific and does not fit into the majority of concepts of organisational development, as in the system of public education (proceeding from its special social role) it is difficult to apply measure indicators of economic character (Jones et al., 2001).

Sustainable development of organisations requires planned changes (Kanter, 1999). Fundamental educational changes include reorganisations in educational ideas, norms, organisational mechanisms, and a framework which constitute education as a social institution. When such changes happen, there can be new educational institutions for addition or replacement of the existing institutions. Assuming as a basis the adduced arguments, management of educational change can be determined as a type of social management.

In the system of scientific knowledge, management of change is part of the theory of organisation, since the middle of the $20^{\text {th }}$ century it has been an independent branch of knowledge and is of applied character.

\section{Management of change as an instrument of organisational development}

Organisational development is a value-oriented process of self-assessment and introduction of the planned changes according to strategic objectives and operational tasks (Kezar, 2001). Management of change is one of the instruments of organisational development. The method of management of projects is a widespread means in practice of management of educational change.

Resistance to educational change arises more from an organisational context in which there is a change, that is (micro political) forces in the system. From here, the integral component of the governance process in educational change derives, as well as the analytical maintenance of organisational readiness (at the level of both the system, separate institutions, and their groups) to the introduction of innovations (Semenets-Orlova, 2018). Resistance to changes at the individual and 
organisational levels can coexist and define the requirement of special instruments of the management of force fields of support and resistance to change in various contexts (Koch, 2004).

If one wants employees to learn quickly and efficiently in accordance with the demands of the modern dynamic world, one should offer them informal corporate programmes of professional improvement. These programmes have the appearance of comfortable educational leisure events, where university staff could periodically meet in small groups (up to 40 people) and study, solving theoretical or practical problems in joint activitiies - of lecturers, the administration, sometimes students.

Lecturers are well-motivated through internal factors. Consequently, periodic surveys of lecturers' opinion, the implementation of programmes to support their pedagogical professionalism in introducing educational change in accordance with the vision of lecturers, the organisation of teachers/lecturers' training in accordance with the content of relevant reforms and transformations in society will become effective tools for motivating the lecturer to work effectively and constantly self-develop.

The largest resource of an innovative university is a creative and initiative lecturer, optimistic and ready to experiment, collaborating with others and sharing newly created knowledge. Such a lecturer will not appear by him- or herself. Only the leadership influence of the university administration will support the motivation of the lecturer at a high level. The main obstacle to supporting such motivation of the teaching staff is still the fear of change and educational reforms, fear of being untenable to work in new conditions. In this context, systematic work on organisational training of lecturers will be more and more in demand at a modern university (Kotter, 1996).

Solving the problems of modern education (in particular, optimising the educational process in higher education institutions) puts forward qualitatively new requirements for technologies for managing human resources in universities. Higher education undergoes a stage of systemic changes, and change is always a learning process (Kotter, 1996). This problem is also very important for any modern employer, since solving the issue of the lack of personnel and training of qualified future personnel begins just with quality education.

Introducing the idea of modernisation is not so easy, especially for a state institution. Taking on this difficult task, the manager should remember that it is always based on the introduction of new management ethics. To introduce the idea of modernising education management provides for the introduction of new ethics of management based on the principles of mutual respect, positive motivation, a positive moral and psychological climate, a developed organisational culture of the institution (Leithwood \& Poplin, 1992). 
It is necessary to take into account social and psychological factors that are directly related to the individual psychological characteristics of workers and the patterns of their communication in groups. This is an essential condition for innovative processes in education, in the formation of a knowledge-based economy.

What is the market demand for a modern lecturer? It must be a person who is:

- taking initiative;

- creative, taking a non-standard approach to business;

- emotionally balanced;

- highly motivated by achievements;

- future-oriented;

- capable of original application of special knowledge in solving professional problems.

The need for change is understandable and well founded. However, in order to achieve sustainable productive communication in the activities of a modern lecturer of an innovative university, special technologies are needed to support its continuous professional improvement by the administration. And frankly speaking, the responsibility of managers at all levels for managing human resources, strengthening the moral and spiritual capital of employees, supporting their innovation is a challenge for management at a modern university. In most cases it is customary to work according to established principles. Innovation often lacks opportunities. But without such innovation the education system has no future, this must be clearly understood.

It is possible to ensure the preparation and implementation of educational changes at different levels of the system due to the creation and mastering of new educational practices:

1) Creation of non-linear situations of open dialogue with direct feedback in the process of knowledge transfer.

2) The perception of training by the participants of this process as a solidarity educational adventure, as a result of solving problem situations, getting into one self-consistent pace of education.

3) Promoting the awakening of lecturers and students of new powers and abilities, discovering themselves, cooperation with other people.

From the point of view of innovative practices, it is precisely such approaches - and not policy guidelines - that will truly optimise all the components of the process: plans, programmes, projects, solutions, and that will reach a completely different quality of management than what we are used to when we say the phrase personnel management at a university. 
Innovative approaches to organisational learning through the joint work of lecturers, students, management and other staff are increasingly seen as part of the concept of its organisational development.

Organisational development programmes help to unleash the leadership potential of the university due to the development of the ability of its staff to respond to changes in society and adjust their goals, structure, and activities accordingly:

- they begin with the processes of self-assessment and change planning;

- on the basis of an assessment of the organisation's capacity, previous development programmes and plans are being developed or updated;

- further activities are carried out directly to fulfill operational tasks of development.

In 2018, the Centre for Organisational Development and Leadership was created in the structure of the Institute of Emerging Technologies and Leadership of the National Aviation University, Ukraine (NAU). The latter identified the following three global perspectives:

1) Continuous monitoring of NAU potential through the following diagnostic measures:

- sociological surveys of lecturers, other employees and students;

- work of focus groups and expert interviews;

- measurement and analysis of the current educational needs of students and the needs of corporate professional development programmes of lecturers and other employees;

- definition and understanding of joint solutions to the problems of the educational process in the university.

2) Implementation of organisational training:

- organisation, on the basis of operational requests of the NAU community, of programmes to improve the competencies of lecturers and students (in the form of short-term seminars on relevant educational and popular science topics);

- conducting professional discussions on relevant topics of the development of science and education, open to the scientific community and the educational community of the city.

3) Development of the organisational culture: the offer on a systematic basis of informal events of educational leisure for employees and students of NAU for development of the organizational culture and the practice of the general (design) activity (for example, workshops, a hackathon and other interactive events of a flexible, dynamic format). This method helps to build the corporate culture of the university and share the results of training on the basis of cooperation, mutual support, encouraging joint experimental work, motivating constant innovative scientific research, and open discussions. 
The main challenge in the Centre's activities is to support continuous institutional improvement through the development of organisational learning through the joint work of all participants in the educational process.

As a result, the knowledge management system at the university is significantly improved:

- the mission of the educational institution is carried out with respect to quality

(and its implementation is monitored);

- student-lecturer-administration feedback is built;

- cooperation between lecturers of various departments, institutes, and faculties is strengthened;

- the psychological climate and the external environment around the educational process are improving, employees receive more decision-making powers, actively assess and accept risks, they are open to change.

Such approaches illustrate one of the procedural ways of introducing the concept of a the learning organisation (according to the theory of Peter Senge), as well as developing the internal environment of the university based on a culture of trust, cooperation, and integrity.

\section{Organisational development, leadership, and values}

Organisational development is a change in all the components of the organisation so that it is more responsive to the demands of a changing external environment and has the task of enhancing its internal capacity to solve existing problems.

Organisational development involves the mandatory intervention of the change agent (leader) in the process of changing the organisation.

This intervention has to be accurately tied to strategic objectives and tasks and to include a certain methodology and approaches:

- strategic planning and organisational design;

- performance management;

- coaching;

- diversity and work-life balance.

Organisational development is a value-based process of self-evaluation and planned changes. They include specific policies and technologies aimed at enhancing the overall effectiveness of the organisational system. At the same time, attention is focused on lecturers and students as the main source of achieving results, and not on some external technical means (which are also needed and useful, but are not the core).

Organisational values work only when they are sincerely shared by all members of the university community (shared values). Values should be perceived as fateful 
both for the university itself and for the external environment. Common vision and mission increase team commitment to their organisation.

Australian educational change researcher William Richard Mulford identifies the following dimensions of organisational learning (Mulford et al., 2002):

- the organisational structure of the institution which allows employees at all levels to constantly learn and share the results of training;

- management of the institution on the principles of participation and involvement, joint decision-making, based on the expansion of the rights and freedoms of lecturers;

- a common vision shared by all members of the team;

- development of knowledge and skills in joint activities;

- leadership;

- effective feedback and accountability.

According to William Richard Mulford, learning organisations are characterised by the following features (Mulford et al., 2002):

- the use methods of scanning the external and internal environment;

- adjusting the development goals which are shared and distributed by the whole team;

- jointly creating an environment of learning/teaching, integration of science and education;

- encouraging initiative and risk-taking;

- regularly reviewing all aspects affecting the work of institutions;

- recognizing and motivating to quality work;

- providing an opportunity for continuous professional development (in particular, the creation of a trusting climate of cooperation).

According to Peter Senge, a well-known researcher who popularised the term the learning organisation, the image of such an organisation becomes a continuation of the vision of every employee who is fully devoted to his or her mission.

\section{Organisational development unit objectives}

The allocation of special structural units in universities that are aimed at organisational development is a fairly common practice, and not only in modern western, but also in domestic universities. Here is the functional load they carry:

- feedback analysis, evaluation of its most efficient channels;

- team building activities (identification of skills required for strategic development tasks, assessment of the need for temporary narrow-sector or cross-functional teams); 
- inter-group work (increasing efficiency of interconnected groups);

- training activities to improve the skills, abilities, and knowledge of the members of the organisation (improvement of both technical skills for effective performance of work tasks, as well as interpersonal communication, social competences);

- structural intervention measures aimed at improving the efficiency of organisational units (experimentation with the creation of new organisational structures and evaluation of their effectiveness, improvement of the organisation by changing tasks, technologies, etc.);

- dissemination of joint decision-making;

- mediation, conflict prevention and resolution;

- development of individual recommendations (training of employees on new ways of behaviour, joint study of alternative ways of behaviour of employees);

- planning of the life and career of employees (activities that help to strengthen the orientation to the human factor, admitting the importance of the quality of work life of employees, which positively affects the motivation to work, and the effectiveness of the organisation as a whole).

Foreign researchers suggest:

- to start organisational development by training people in managerial skills, development of leadership skills;

- then to concentrate on improvement and development of teams;

- further, to move to the development of intergroup relations;

- then, to engage in corporate planning, development of tactical skills of plan execution;

- the final phase - assessment of changes in the organisational culture and determination of future directions of work.

\section{Organisation of joint activities}

One of the most common approaches to organisational training is the organisation of joint activities of lecturers (and other university staff) according to the model of team management in business.

In the 1980s and 1990s the problem of joint activities in the organisation was defined as a psychological phenomenon of the team (and some psychologists considered joint activities as one of the main types of human communication).

The contribution of each employee to the end result is important for interaction to be effective. However, research shows that not every group has a preference for joint activities, so it needs to be supported further through managerial impact. 
In the group a person rejects more easily bad habits or previous norms, perceives more easily the new ones. That is why at the stage of thawing (in the process of introducing changes), methods of group training, collective search for organisational solutions are used: brainstorming, intensive problem meetings, etc.

Joint activity is an organised system of activity of interacting individuals, aimed at fulfilling a certain task, during which subjects alternately and mutually change each other's social and psychological states, values, and intentions.

Scientists advise managers in each individual case to decide whether the employee is ready for joint activities and only then select the appropriate working methods. If the group does not cope well with joint work, then the leader is to blame for this: it means that he/she did not prepare people for it. The table shows important markers of joint activities.

In 2018-2019, about 400 teachers completed various training programmes at the Centre for Organisational Development and Leadership. The authors conducted a study of feedback questionnaires of the participants about their understanding of markers of joint activities. The results of the survey are presented in Table 1.

Table 1. Main markers of joint activities

\begin{tabular}{|l|l|}
\hline Mandatory psychological & general motivation \\
\cline { 2 - 2 } $\begin{array}{l}\text { components of joint } \\
\text { activities }\end{array}$ & joint actions \\
\cline { 2 - 2 } & overall outcome (and its reflection by individual and collective actors) \\
\hline $\begin{array}{l}\text { Components of joint } \\
\text { business management }\end{array}$ & stimulating the social and cultural creativity of the workers themselves \\
\cline { 2 - 2 } & $\begin{array}{l}\text { direct participation in the organisation and management of joint } \\
\text { activities }\end{array}$ \\
\cline { 2 - 2 } & mutual control, mutual assistance, and replacement of each other \\
\cline { 2 - 2 } & clarity in understanding common goals and values \\
\cline { 2 - 2 } & collective responsibility for results \\
\hline Characteristics of joint & creating an informal environment for communication \\
\cline { 2 - 2 } activities & using innovative vocabulary \\
\cline { 2 - 2 } & inviting interesting speakers who have non-standard working methods \\
\hline
\end{tabular}

Source: own study.

In the logic of high-quality joint activities, on 31 January this year an open dialogue was held on the future of Ukrainian universities, entitled Finds of progressive lecturers of the city of Kiev, on the initiative of the "Platform of the Progressive Lecturer" social organisation and the Centre for Organisational Development and Leadership of NAU, in cooperation and partnership with the social institutions: "Social Democratic Platform" and "The Institute for Democracy and Social Progress". 
During this event, in its first part, the invited speakers outlined the scope of opportunities and risks of introducing the international experience of educational reforms.

In the second part, all the lecturers discussed what should be used from international experience (and if this is really possible) for the development of innovative universities in Ukraine. The teamwork of our colleagues showed how easy it is to find more correct solutions together.

\section{Conclusion}

With the advent of the team spirit, the approval of a new corporate culture, value orientations and ideals of behaviour, the processes of organisational training at the university do not end. They must become continuous. And for this it is necessary to create a system of constant monitoring of interpersonal relations of employees, analysis of group dynamics and psychological correction of conflicts as a possible consequence of dynamic processes of organisational development.

In universities, hard work is under way to find the place of educational institutions with a modern constantly changing world. The National Aviation University is among the leaders of this process, interested in partnership with business. The Centre for Organisational Development and Leadership of the Institute of Emerging Technologies and Leadership of the NAU is an innovative laboratory, the experience of which we are ready to share with all interested market participants.

Further areas of research - practical study of specific cases of educational change - may determine their effectiveness to ensure the development of human potential.

The paper is written under the framework of the project Realization of the young scientists' potential in integration of science, education, and business (Ukrainian state registration number 0120U102126).

\section{References}

Jacobsen, C., \& Andersen, L. (2013). Performance Management in the Public Sector: Does It Decrease or Increase Innovation and Performance? International Journal of Public Administration, 37, 1011-1023.

Jacobsen, C., Hvitved, J., \& Andersen, L. (2013, March). Command and motivation: How the perception of external interventions relates to intrinsic motivation and public service motivation. Public Administration. Advance Online Publication, 92(4). 
Jones, R., Thompson, F., \& Zumeta, W. (2001). Public management for the new millennium: developing relevant and integrated professional curricula? Retrieved from: http://journals. sfu.ca/ipmr/index.php/ipmr/article/download/188/188/ (accessed: 1.12.2020).

Kanter, R. (1999). Change is everyone's job: Managing the extended enterprise in a globally connected world. Organizational dynamics, 28(1), 7-23.

Kezar, A. (2001). Understanding and Facilitating Organizational Change in 21th Century: Recent Research and Conceptualizations. Higher Education Report, 28, 4, San Francisco: Jossey-Bass.

Koch, A. (2004). Change Kommunikation. Marburg: Tectum Verl.

Kotter, J. (1996). Leading change. Boston: Harvard Business School Press.

Kruchovski, P. (2016). 9 ways to make education fit for the 21 ${ }^{\text {st }}$ century, World Economic Forum. Retrieved from: https://www.weforum.org/agenda/2016/07/9-ways-tomake-education-fit-for-the-21st-century?utm_content=buffer1a29c\&utm medium=social\&utm_source=twitter.com\&utm_campaign=buffer (accessed: 3.12.2020).

Leithwood, K., \& Poplin, M. (1992). Toward Transformational Leadership, Educational Leadership. 49(5), 8-12.

Levine, D., \& Cooper, E. (1989). The Change Process and Its Implications in Teaching Thinking. In: Lorna Idol, Beau F. Jones (Eds.), Educational Values and Cognitive Instruction (pp. 387-410). Hillsdale, NJ: Lawrence Erlbaum.

Lewin, K. (1947). Frontiers in Group Dynamics. Human Relations 1 (5-41). Retrieved from: https://journals.sagepub.com/doi/abs/10.1177/001872674700100201 (accessed: 4.12.2020).

Lewin, K. (1952). Field Theory in Social Science: Selected theoretical papers. London: Tavistock. Mulford, R., Silja, W., Claudia, H., \& Zarins, S. (2002). Organizational Learning and School Change. Educational Administration Quarterly, 38(5), 613-642.

Semenets-Orlova, I. (2017). Processual aspects of educational changes: empirical findings at institutional level. Advanced Education, 1(7), 64-67.

Semenets-Orlova, I. (2018). Tendencies in reforming the educational system of modern Ukraine: national and regional aspects. Public management: collection, 2(12), 171-179.

\section{Inna Semenets-Orlova}

Holds a Master's degree in political science and law. Since 2014 engaged in developing and management of educational and research projects, cooperated with the Swiss Agency for Development and Cooperation SDC, Pädagogische Hochschule Zürich, Polish Aid. Research interests: state policy, regional development, support of civic activity to solve environmental problems in the regions of Ukraine. The author of more than 160 scientific papers, national expert of Swiss-Ukrainian projects: the DOCCU Project №7F-08698.01 and DECIDE, Laureate of the 
"Innovative Intellect of Ukraine" Honorary Silver Badge, winner of international competitions for scientific works of young scientists in public administration, a member of a number of official working groups, international internships: of Warsaw University, Jagiellonian University, individual grant from the Government of the Swiss Confederation to conduct a mass survey in 6 regions of Ukraine, collective grant from Deutsche Gesellschaft für Internationale Zusammenarbeit (GIZ Ukraine) $\mathrm{GmbH}$ to learn civic position in 8 regions of Ukraine. A member of the working groups on the development of the "Concept of development of citizenship education in Ukraine" and the "Strategy for the development of citizenship education for the period up to 2022", a participant of meetings of a working group on preparation of a draft law on education for the second reading (2016, 2017). Doctor of Public Administration, Associate Professor, Head of the Department of Public Administration at Interregional Academy of Personnel Management.

e-mail: innaorlova@ukr.net

ORCID: 0000-0001-9227-7426

\section{Hanna Kuzmenko}

Holds a Specialist Diploma in Law, expert in NGOs, a project monitoring specialist. Key responsibilities from January 2016 up to the present day include: doing scientific research in the field of management of educational change; analytical activity; projecting and implementation of educational change at the lowest operational level of a higher educational institution (e.g., a department), as well as at the level of a higher educational institution as a whole; organisation and conducting of communication activities, educational master classes, workshops. Postgraduate student at the Department of Public Administration, Interregional Academy of Personnel Management.

e-mail: anna-kuzmenko96@ukr.net

ORCID: 0000-0003-0672-7633 